\title{
THE EFFECT OF SOLID PARTS ON THE NON-LINEAR BEHAVIOR OF ONE WAY RIBBED SLABS
}

\author{
M. H. Ahmed*, Y. A. Hassaneen*, \\ Z. E. Abd EI Shafy **; and M. A. Farouk ${ }^{* * *}$ \\ Civil engineering Department, faculty of Engineering, Assiut University \\ *Professor at civil En. Dept., Faculty of Eng., Assiut University \\ ** Lecturer, Civil Eng. Dept., Assiut University. \\ ***Engineer Expert in Ministry of justice.
}

(Received October 12, 2010 Accepted November13, 2010)

\begin{abstract}
Non-linear behavior of one way ribbed slabs was introduced in this paper. The 3D-FEM model through (ANSYS) program has been used to accomplish this study. In this research the effect of width of middle solid part, the area of compression reinforcements of middle solid part and the width of edge solid parts on the behavior of one way ribbed slabs were studied. The ultimate load, the cracking load, the strain of concrete, stress of steel and deflection were calculated as well as mode of failure was observed. The best ratio of the width of middle solid part to the span of slab and the effect of existence the edge solid parts were concluded.
\end{abstract}

\section{1- INTRODUCTION}

The ribbed slabs are common types of slabs. The main advantages of using ribbed slabs are permitting a given minimum clear height to be maintained with a reduced overall story height, covering a big horizontal area, simple formwork and reduced own weight. The system exhibits higher stiffness and smaller deflections.

The solid parts are very important elements in the structural system of ribbed slabs. The solid parts used at the connection of the ribs with the supported beams to resist the straining actions which are higher than the loading capacity of the ribs. Also the solid parts can be used as hidden supported beams for the slabs. So the solid parts can affect the behavior and the loading capacity of ribbed slabs.

Many factors affect the efficiently of the solid parts such as the width of solid part and the compression steel reinforcements

The analysis of ribbed slabs by using structural codes such as ACI 318-02 (1), BSI (2) and ECP 203 (6), do not recommend certain limits for the width and the compression steel reinforcements of the solid part without beam. Where the solid part is analyzed as hidden beam, and the width and the compression steel are determined on this principle. ECP 203 recommends for the edge solid parts that the minimum width is $0.2 \mathrm{~m}$ or one half the space between ribs to resist the induced shear forces of the ribs and top slab.

Continuous one way ribbed slabs were analyzed in this work by using finite element method through ANSYS program. The used models illustrated the non-linear behavior of one way ribbed slabs. Also the effect of width of middle solid part, area of compression steel of middle solid parts and the width of edge solid parts on the behavior of the ribs and the middle solid parts were studied. 


\section{2- NUMERICAL STUDY}

\subsection{Constitutive Model}

\section{Concrete Constitutive Model}

Solid65, an eight node solid element, is used to model the concrete with or without reinforcing bars. The solid element has eight nodes with three degrees of freedom. The element is capable of having plastic deformation, cracking in three orthogonal directions, and crushing. The geometry and node locations for this element type are shown in Fig. (1).

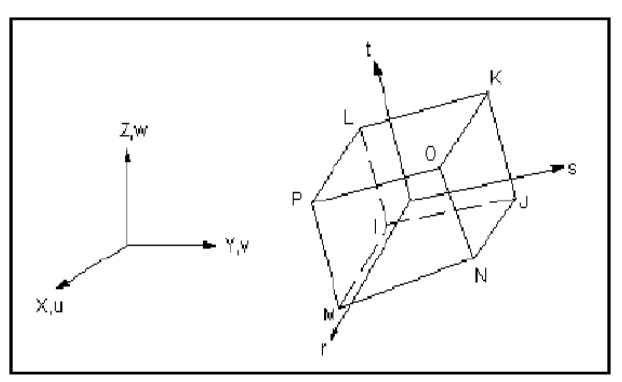

Fig. (1) Solid 65-3D reinforced concrete element

The input data are elastic modulus $\left[E_{c}\right]$, ultimate uniaxial compressive strength $\left[f_{c}^{-}\right]$ultimate uniaxial tensile strength [modulus of rapture $\left[f_{r}\right]$ Poisson's ratio $(v)$, density $(\gamma)$, shear transfer coefficient for an open crack $\left(\beta_{t}\right)$, shear transfer coefficient for a close crack $\left(\beta_{c}\right)$ and compressive uniaxial stress strain relationship of concrete.

The elastic modulus of elasticity is obtained by the pulse velocity method and can be calculated by means of its ultimate concrete compressive strength by using Equation (1) ACI_318 [1]

$$
f_{c}^{\prime}=\left[\frac{E c_{c}}{4730}\right]^{2}
$$

Where:

$\left[E_{c}\right]$ Elastic modulus of concrete in MPa .

$\left\lfloor f_{c}^{-}\right\rfloor$Ultimate compressive strength of concrete in MPa.

The tensile strength of concrete is $8-15 \%$ of the compressive strength Shah, et al 1995[8]. $1989[2]$.

A typical stress- strain curve for concrete is shown in Fig. (2) Bangash 


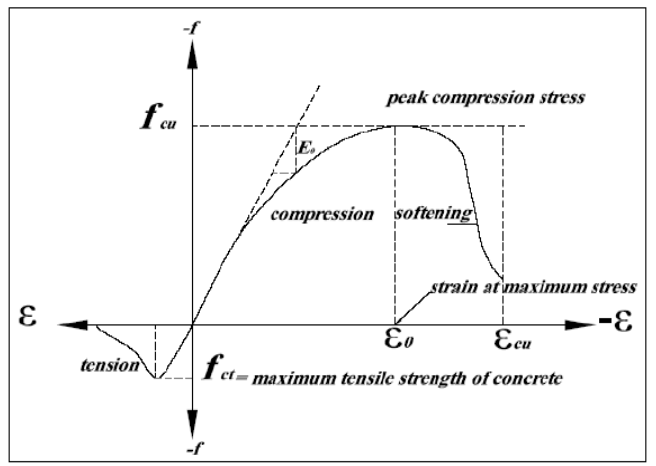

Fig. (2) Typical uniaxial compressive and tensile stress-strain curve for concrete (Bangash 1989).

Numerical expressions of Desayi and Krishnan 1964 [5], Equations (2) and (3) are used to construct the uniaxial compressive stress-strain curve for concrete.

$$
\begin{aligned}
& f=\frac{E_{c} x \varepsilon}{1+\left(\frac{\varepsilon}{\varepsilon_{0}}\right)} \\
& \varepsilon_{0}=\frac{2 f_{c}^{\prime}}{E_{c}} \\
& E_{c}=\frac{f}{\varepsilon} \\
& f \quad=\text { stress in MPa at strain } \varepsilon \\
& \varepsilon \quad=\text { strain at stress } f \\
& \varepsilon_{0} \quad=\text { strain at the ultimate compressive strength. }
\end{aligned}
$$

The values of the considered parameters are presented in table 1

Table 1

\begin{tabular}{|c|c|c|c|c|c|}
\hline$\left[E_{c}\right] \mathrm{kg} / \mathrm{cm}^{2}$ & $(v)$ & $\left(\beta_{t}\right)$ & $\left(\beta_{c}\right)$ & {$\left[f_{c t}\right\rfloor \mathrm{kg} / \mathrm{cm}^{2}$} & {$\left[f_{c}^{-}\right\rfloor \mathrm{kg} / \mathrm{cm}^{2}$} \\
\hline $2.0 \times 10^{5}$ & 0.2 & 0.2 & 0.5 & 25 & 250 \\
\hline
\end{tabular}

\section{Reinforcement constitutive model}

The reinforcement has been modeled as a discrete reinforcement (Link8) throughout the element (solid65).

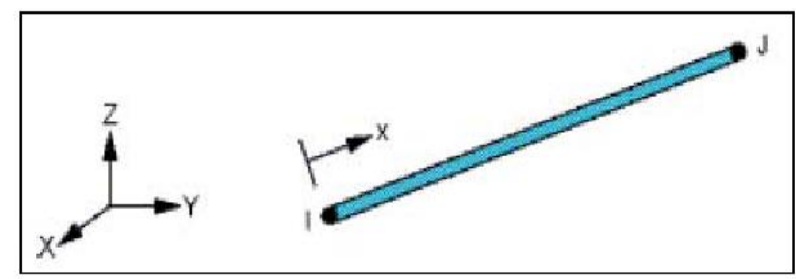

Fig. (3) 8-3D bar element. 
The element is capable of having plastic deformation, stress stiffening, and large deflection. The geometry, node locations, and the coordinate system for this element are shown in Fig. (3).

The considered steel reinforcement was typical grade 360/520 with Poisson's ratio 0.3. The steel was assumed elastic-perfectly plastic material (Bilinear Isotropic Hardening) and identical in tension and compression. These options used the von Mises yield criterion with the associated flow rule and isotropic work hardening. Fig. (4) shows stress-strain relationship used in this study.

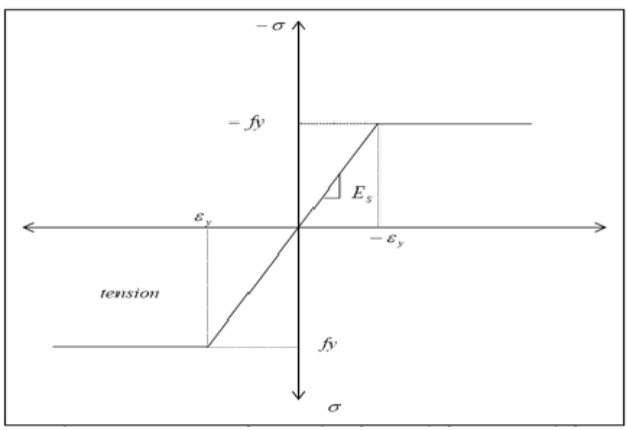

Fig. (4) Steel stress-strain relationship used in this study

\subsection{Geometrical Modeling}

- Only one quarter of the model was solved due to symmetry.

- The uniform load applied on slabs was taken as a concentrated load at the intermediate point of each element. Fig. (5) illustrates the applied loading.

- The symmetry boundary conditions were set first. The model being used was Symmetrical about two planes. The boundary conditions for both planes of symmetry are shown in Fig. (6).

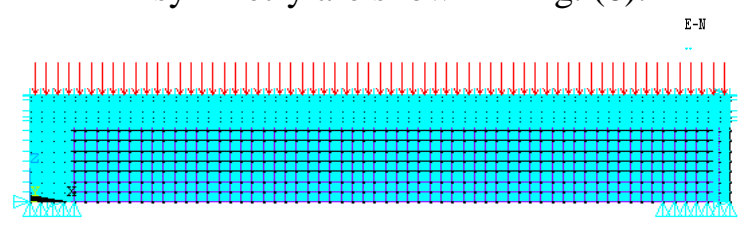

Fig (5) Pressure on the elements

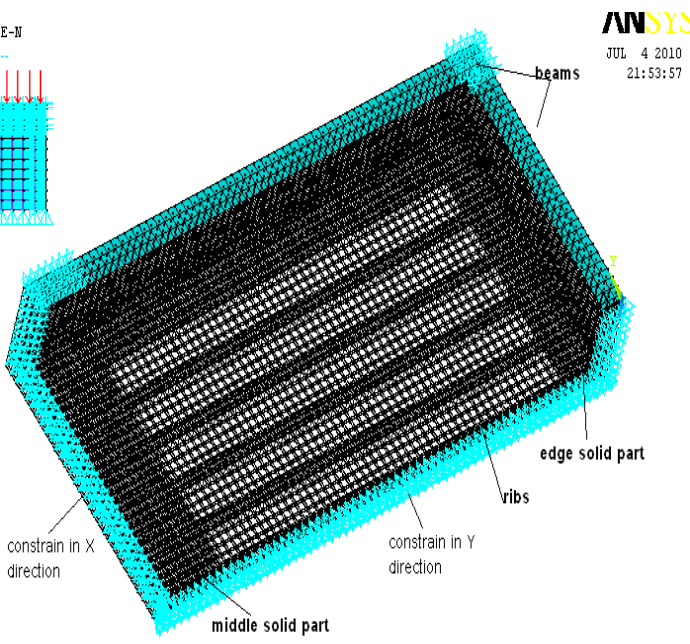

Fig (6) Boundary Condition for the model 
- The full and quarter models of the reference slab were analyzed. The both of two models gave the same results. So the slabs in this study were analyzed as quarter models.

\subsection{Studying Parameters}

One way ribbed slabs were analyzed by finite element method by using ANSYS program. The effect of the following variables were studied:-

- The width of middle solid part

- The ratio of compression steel to the tension steel area of middle solid part

- The width of edge solid parts

Fifteen two bays slabs were analyzed to study these variables. The reference slab had dimensions $6 \times 6 \mathrm{~m}$ for each bay. The ribs had cross section $0.1 \times 0.25 \mathrm{~m}$ and top slab thickness $0.05 \mathrm{~m}$. The net space between ribs was $0.4 \mathrm{~m}$. The width of middle solid part was $1.8 \mathrm{~m}$ and width of edge solid parts in each of both two directions were $0.3 \mathrm{~m}$. The supported beams had section $0.3 \times 1.05 \mathrm{~m}$. The tension reinforcement of the ribs were (2Ф16). The main reinforcement of middle solid part was (17Ф22) and compression steel was $(19 \Phi 16)$. The reinforcement of edge solid parts was (3Ф12) at each of top and bottom surface. See table 2

Table 2. Parameters of the study

\begin{tabular}{|c|c|c|c|c|c|c|}
\hline \multirow{3}{*}{ Groups } & \multirow{3}{*}{ slab No. } & \multicolumn{2}{|c|}{ middle soild part } & \multirow{2}{*}{\multicolumn{2}{|c|}{ edge solid parts }} & \multirow{3}{*}{ notes } \\
\hline & & \multirow{2}{*}{$\begin{array}{l}\text { width of } \\
\text { solid part }\end{array}$} & \multirow{2}{*}{$\begin{array}{c}\text { percentage of } \\
\text { compresion } \\
\text { steel " } \alpha \text { " }\end{array}$} & & & \\
\hline & & & & $\begin{array}{l}\text { perpendic- } \\
\text { ular of ribs }\end{array}$ & $\begin{array}{c}\text { parallel of } \\
\text { ribs }\end{array}$ & \\
\hline ** & Sr & $30 \% \mathrm{~L}$ & 0.6 & $0.3 \mathrm{~m}$ & $0.3 \mathrm{~m}$ & - \\
\hline \multirow{4}{*}{ A } & A1 & $23.33 \% \mathrm{~L}$ & 0.6 & 0.3 & 0.3 & \multirow{4}{*}{$\begin{array}{l}\text { effect of width of } \\
\text { middle solid part }\end{array}$} \\
\hline & A2 & $26.67 \% \mathrm{~L}$ & 0.6 & 0.3 & 0.3 & \\
\hline & A3 & $33.33 \% \mathrm{~L}$ & 0.6 & 0.3 & 0.3 & \\
\hline & A4 & $36.67 \% \mathrm{~L}$ & 0.6 & 0.3 & 0.3 & \\
\hline \multirow{4}{*}{ B } & $\overline{\mathrm{B} 1}$ & $30 \% \mathrm{~L}$ & 0.2 & 0.3 & 0.3 & \multirow{4}{*}{$\begin{array}{c}\text { effect of } \\
\text { compresion steel of } \\
\text { s.p }\end{array}$} \\
\hline & B2 & $30 \% \mathrm{~L}$ & 0.4 & 0.3 & 0.3 & \\
\hline & B3 & $30 \% \mathrm{~L}$ & 0.8 & 0.3 & 0.3 & \\
\hline & B4 & $30 \% \mathrm{~L}$ & 1 & 0.3 & 0.3 & \\
\hline \multirow{3}{*}{$\mathrm{K}$} & $\overline{\mathrm{K} 1}$ & $30 \% \mathrm{~L}$ & 0.6 & 0 & 0.3 & \multirow{3}{*}{$\begin{array}{c}\text { effect of edge SP } \\
\text { perpendicular of ribs }\end{array}$} \\
\hline & $\mathrm{K} 2$ & $30 \% \mathrm{~L}$ & 0.6 & $8.33 \% \mathrm{~L}$ & 0.3 & \\
\hline & K3 & $30 \% \mathrm{~L}$ & 0.6 & $13.33 \% \mathrm{~L}$ & 0.3 & \\
\hline \multirow{3}{*}{$\mathrm{L}$} & L1 & $30 \% \mathrm{~L}$ & 0.6 & 0.3 & 0 & \multirow{3}{*}{$\begin{array}{c}\text { effect of edge SP } \\
\text { parallel of ribs }\end{array}$} \\
\hline & L2 & $30 \% \mathrm{~L}$ & 0.6 & 0.3 & $8.33 \% \mathrm{~L}$ & \\
\hline & L3 & $30 \% \mathrm{~L}$ & 0.6 & 0.3 & $13.33 \% \mathrm{~L}$ & \\
\hline
\end{tabular}

\section{The Analyzed Slabs Were Divided In Groups As Follows:-}

Group A: - The width of middle solid part of slabs A1, A2, A3 and A4 were 1.4m, $1.6 \mathrm{~m}, 2 \mathrm{~m}$ and $2.2 \mathrm{~m}$ that equal to $23.33 \% \mathrm{~L}, 26.67 \% \mathrm{~L}, 33.33 \% \mathrm{~L}$ and $36.67 \% \mathrm{~L}$ respectively.

Group B:- The ratio of compression steel to tension steel of solid part of slabs B1, B2, B3, B4 were $0.2,0.4,0.8$ and 1 respectively. 
Group K: - The width of perpendicular edge solid part of the ribs for slabs K2 and K3 were $0.5 \mathrm{~m}$ and $0.8 \mathrm{~m}$ that equal to $8.33 \% \mathrm{~L}$ and $13.33 \% \mathrm{~L}$ respectively. Where slab K1 was without perpendicular edge solid part.

Group L: - The width of parallel edge solid part of the ribs for slabs L2 and L3 were $0.5 \mathrm{~m}$ and $0.8 \mathrm{~m}$ that equal to $8.33 \% \mathrm{~L}$ and $13.33 \% \mathrm{~L}$ respectively. Where slab $\mathrm{L} 1$ was without parallel edge solid part.

\subsection{Results and Discussion}

\subsubsection{The Effect of Width of Middle Solid Part}

\subsubsection{1)- Pattern of Cracks and Mode of Failure.}

At the top surface of reference slab, vertical cracks in plane $\mathrm{YZ}$ were initiated at load $0.65 \mathrm{t} / \mathrm{m}^{2}$ "which equals $19.4 \%$ of ultimate load" at the connection between top slab and edge solid part which is parallel to ribs. These cracks separated through the width of slab. At load $0.9 \mathrm{t} / \mathrm{m}^{2}$, other vertical cracks in plane $\mathrm{XZ}$ were initiated at the connection between the middle rib and edge solid part perpendicular on. With increasing the load the cracks formed at the connection between the other ribs and edge solid part. At load $1.3 \mathrm{t} / \mathrm{m}^{2}$, vertical cracks in plan XZ were initiated at the connection between the ribs and middle solid part and extended to the mid of solid part at load 1.6 $\mathrm{t} / \mathrm{m}^{2}$. In addition, it can be noted through the difference steps of loading that cracks formed at the end of middle solid part at the support and another cracks occurred at the contact of supported beams with edge solid parts. The pattern cracks are as shown in Fig. (7)

At the bottom surface of slab, vertical cracks in plane $\mathrm{YZ}$ were initiated at load $0.6 \mathrm{t} / \mathrm{m}^{2}$ at the mid section of middle solid part. With increasing load until failure of slab, these cracks separated near the end of solid part at the support and grew vertical in the height of the solid part. Also at load $0.75 \mathrm{t} / \mathrm{m}^{2}$, cracks in plane $\mathrm{XZ}$ were initiated at mid section of the middle rib then with increasing load these cracks formed at the other ribs. With increasing the load the cracks which occurred at the ribs separated through the mid third of span and grew vertical in the height of the ribs. At the near of ultimate load diagonal cracks occurred at the third ends of ribs at its connection with solid parts. These cracks formed at starting of the web of the rib from up. Also at the near of ultimate load, diagonal cracks in plane $\mathrm{YZ}$ occurred at the end of middle solid part at the support. At the top slab, cracks in plane $\mathrm{YZ}$ were occurred at the bottom layer between space of ribs and in the top layer at the connection between slab and edge part. It is noted that no cracks occurred at the top layer at connection of slab with ribs.

The pattern of cracks of all study slabs in this work were similar to the pattern of cracks of reference slab.

The final modes of failure for slabs of group "A" and reference slab were tension flexural failure caused by yielding of the tension reinforcement of middle solid part. 


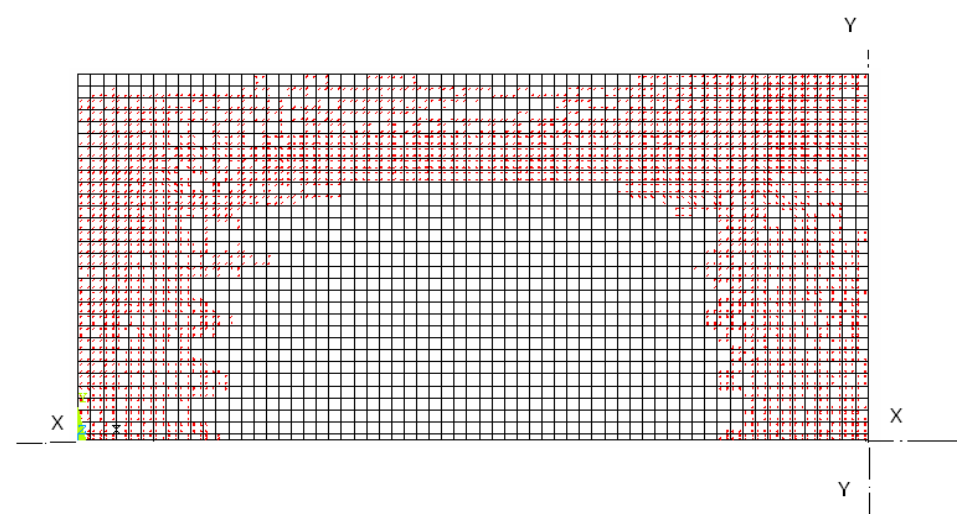

Fig. (7) the cracks at top surface for quarter of reference slab at ultimate load

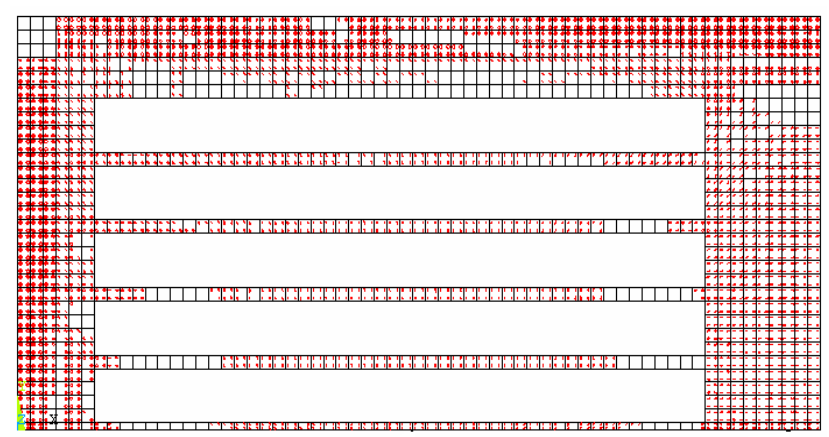

Fig. (8) The cracks of bottom surface for quarter of reference slab at ultimate load

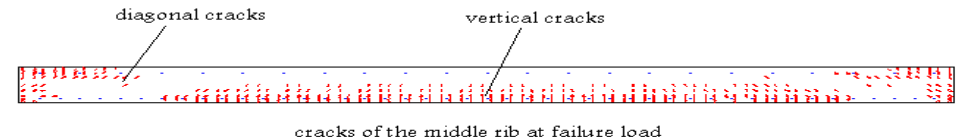

Fig. (9) The cracks of middle rib at failure load

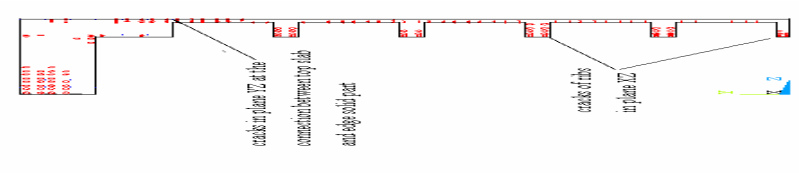

Fig. (10) The cracks of section in the ribs at failure load

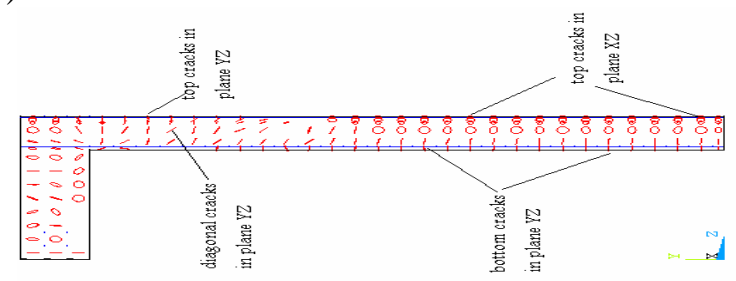

Fig. (11) the cracks of section in middle solid part at failure load 


\subsubsection{2)- Cracking and Ultimate Loads.}

The relationship between $\mathrm{B} / \mathrm{L} \%$ and Pcr is shown in Fig (12)

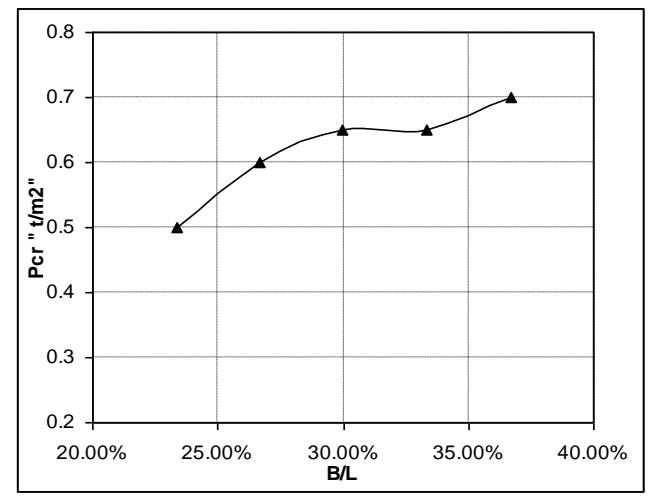

Fig. (12) The relationship between B/L and Pcr

From investigation of Fig. 12, it is clear that the cracking load increases as the width of middle solid part increases. The cracking load of slabs was occurred at the mid section of middle solid part.

It was observed that with increasing width of middle solid part from $23.33 \% \mathrm{~L}$ to $30 \% \mathrm{~L}$, the ultimate load of slabs increased by ratio $4.7 \%$. But with increasing width of middle solid part over than $30 \% \mathrm{~L}$ until $36.66 \% \mathrm{~L}$, the ultimate load of slabs decreased as shown in Fig. (13). This is may be due to increase width of solid part over than $30 \% \mathrm{~L}$ until $36.66 \% \mathrm{~L}$, the loads which are separated on the solid part direction increase with big ratio and causes increasing induced moment at mid section of solid part. This moment is bigger than the increasing of capacity moment of solid part section.

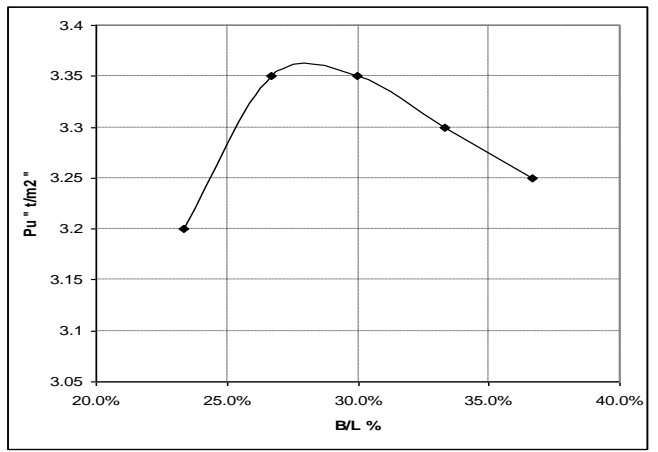

Fig (13) The relationship between $\mathrm{B} / \mathrm{L} \%$ and $\mathrm{Pu}$

\subsubsection{3) Deformations and Stress of the Middle rib and Solid Part .}

The relationship between $\mathrm{B} / \mathrm{L} \%$ and maximum deflection at mid section of middle rib, and the load deflection curve are shown in Figs (14 and 15) respectively.

It was observed that the maximum deflection decrease as the width of middle solid part increase. The maximum deflection of the slabs occurred at the mid section of the middle rib. 


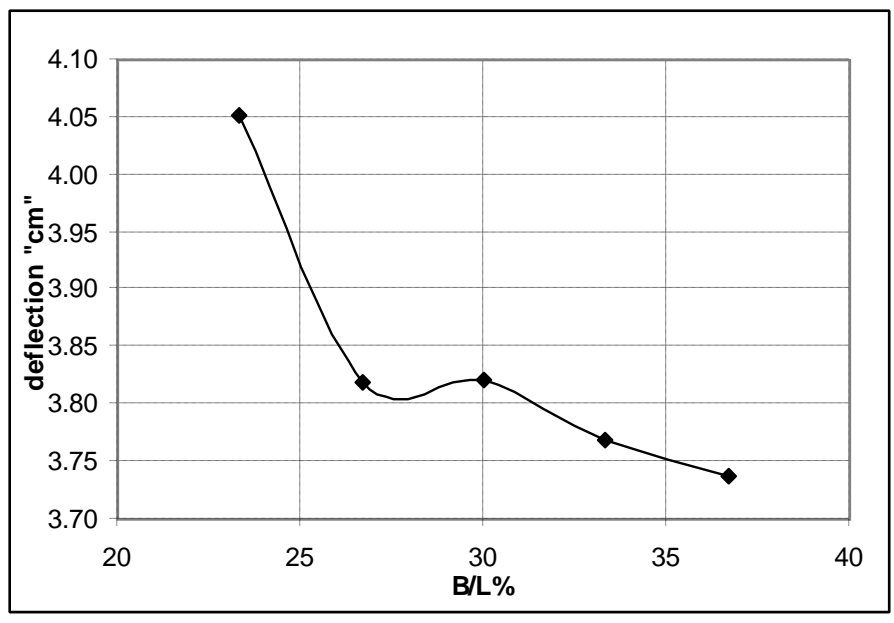

Fig. (14) The relationship between B/L\% and maximum deflection at mid section of middle rib

The change of width of middle solid part has small effect on the increase of rigidity of slab as shown in Fig. (15).

Increasing the width of middle solid part, the strain of concrete and stress of steel at mid section of the rib decrease. This is due to the decrease of length of the ribs. See Fig 16 a and $b$.

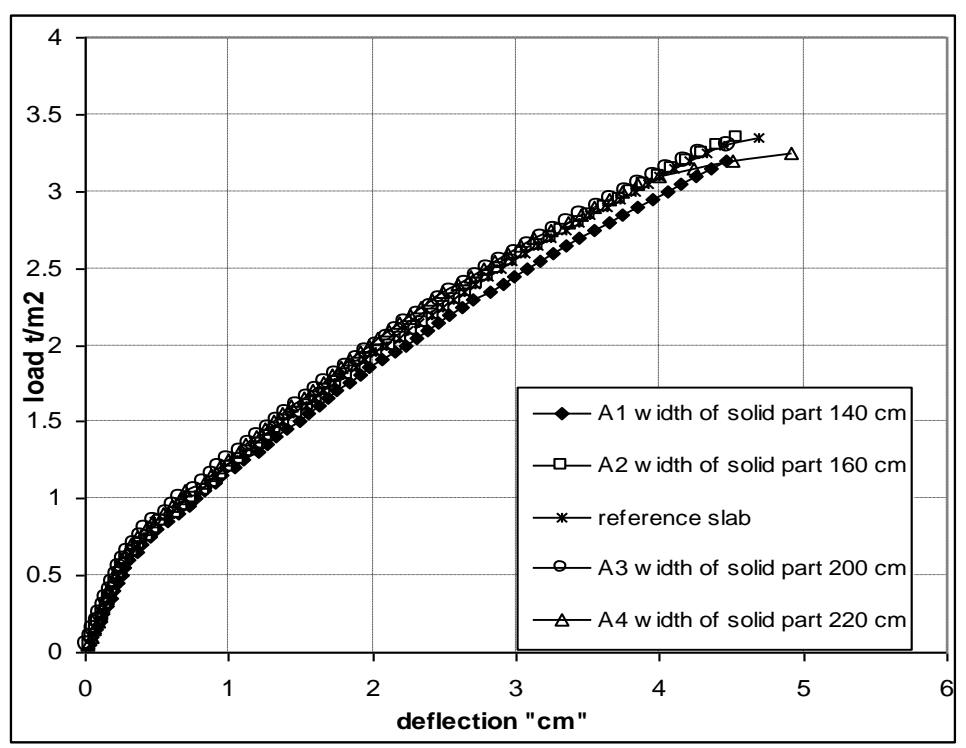

Fig. (15) The load - deflection curve at mid section of middle rib 


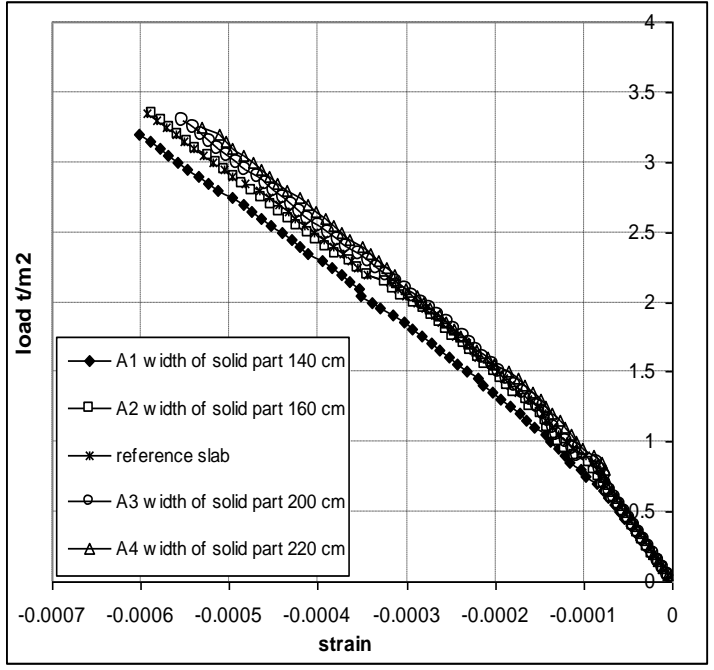

(a) load-strain curve of concrete at top fibers

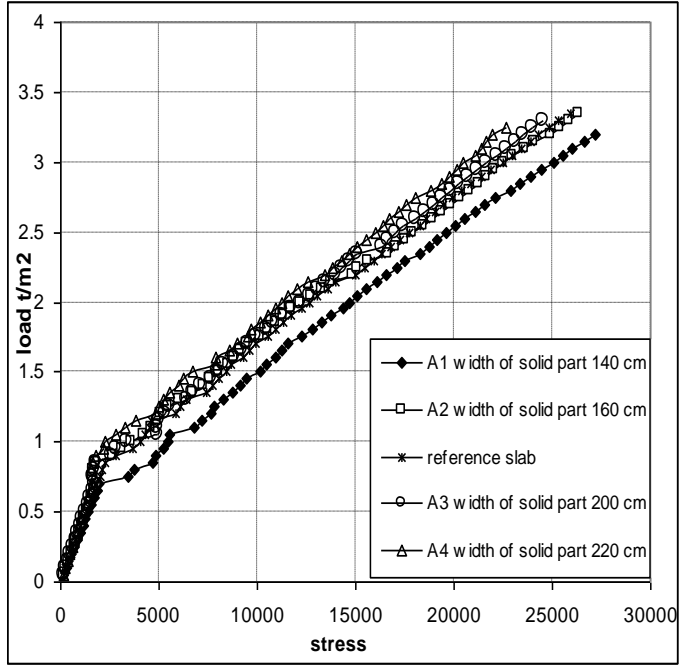

(b) load-stress" $\mathrm{t} / \mathrm{m}^{2}$ " curve of steel at bottom fibers

Fig. (16) load-strain and stress curve at mid section of the rib

The load deflection curve, The load - strain curve of concrete and the load stress curve of steel at the middle of solid part are shown in Figs (17 and 18) respectively.

It was observed that the maximum values of deflection at mid span of solid part are in slabs A1 and A4 and are bigger than their values in other slabs. This is may be because that the cross section of solid part in slab A1 is small which means small stiffness "EI". While the big width of solid part in slab A4 causes increasing the separated load in solid part direction and increasing the deflection.

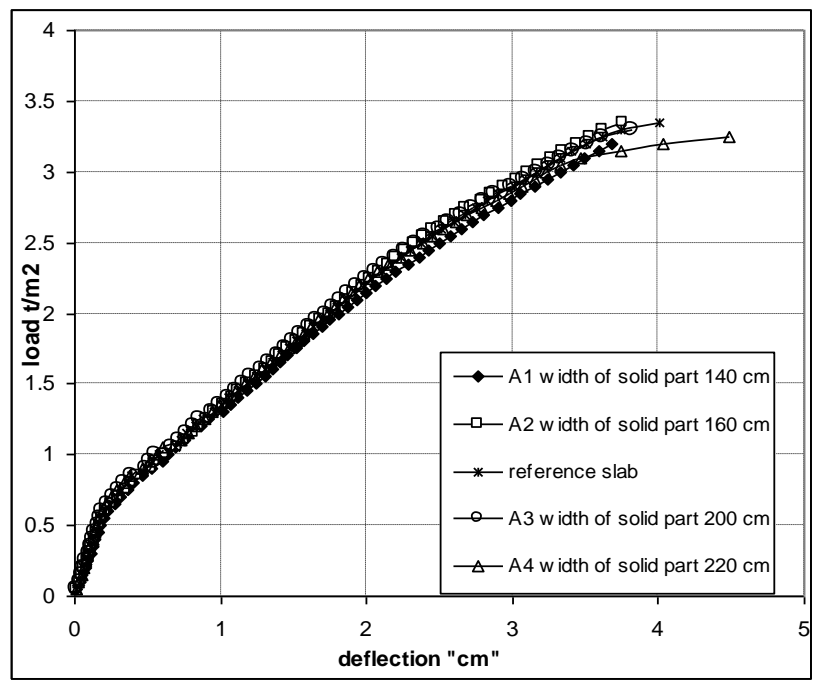

Fig (17) load-deflection curve at mid span of solid part 


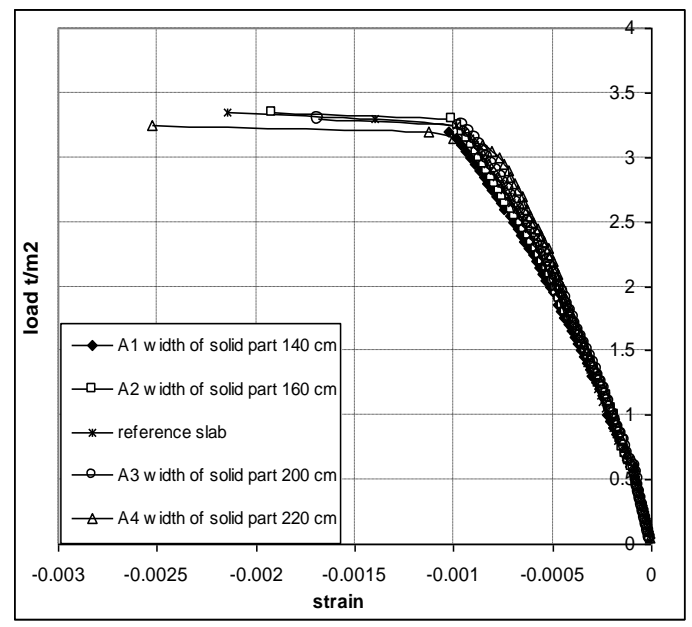

a) load-strain curve of concrete at top fibers at mid section of solid part

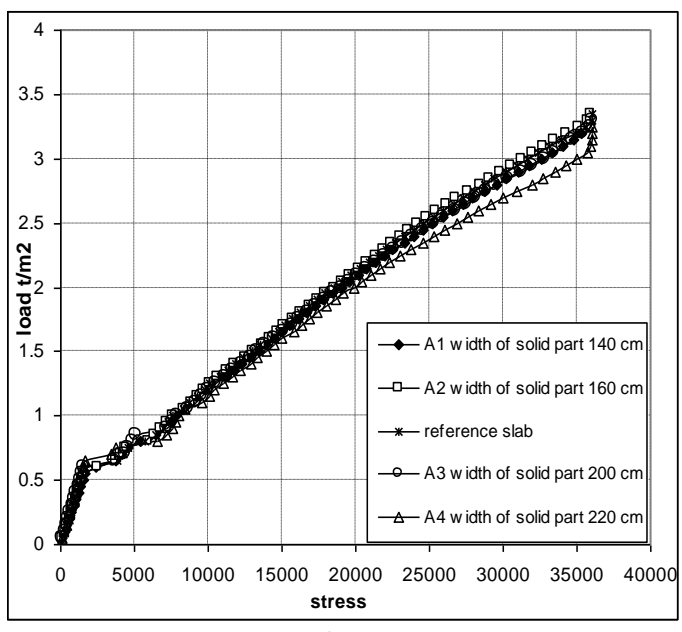

(b) load-stress $\left(\mathrm{t} / \mathrm{m}^{2}\right)$ curve of steel at bottom fibers at mid section of solid part

\subsubsection{The Effect of Compression Steel of Middle Solid Part}

\subsubsection{1)- Cracking Load, Modes of Failure and Ultimate Load .}

The change of compression steel of middle solid part has little effect on the cracking load and the values of cracking load are nearly equal to their values of reference slab

The final modes of failure for slabs "B2, B3 and B4" were tension flexural failure caused by yielding of the tension reinforcement of middle solid part. While the final mode of failure for slab B1 was compression failure at mid section of solid part.

It was noted that with increasing the ratio of compression steel over than 0.6, the ultimate load was slightly affected.

The relationship between compression steel to tension steel ratio of solid part and ultimate load is shown in Fig. 19.

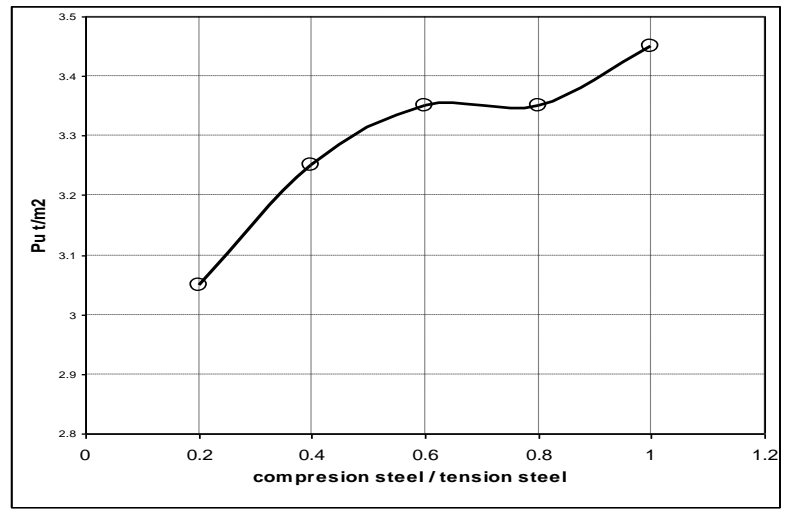

Fig. (19) The relationship between failure and compression steel to tension steel ratio 


\subsubsection{2)- Deformations and Stress of the Middle Rib and Solid Part.}

The relationship between the ratio of compression steel to tension steel and maximum deflection at mid section of middle rib and the load deflection curve are as shown in Figs. (20 and 21) respectively.

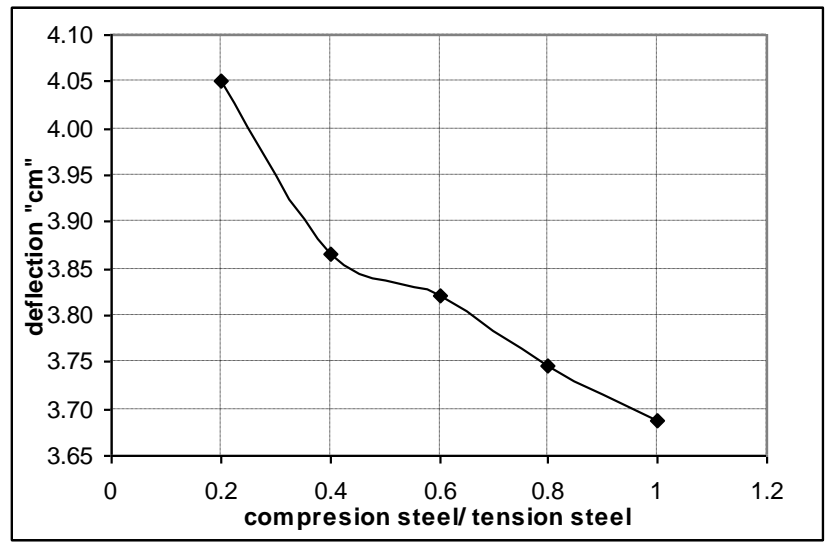

Fig. (20) The relationship between the ratio of compression steel to tension steel and maximum deflection at mid section of middle rib

Increasing the compression steel, the maximum deflection at the middle of rib decreases and the stiffness of slab increases. This is may be because with increasing the compression steel, the rigidity of middle solid part increases which is acted as supported beam for the ribs.

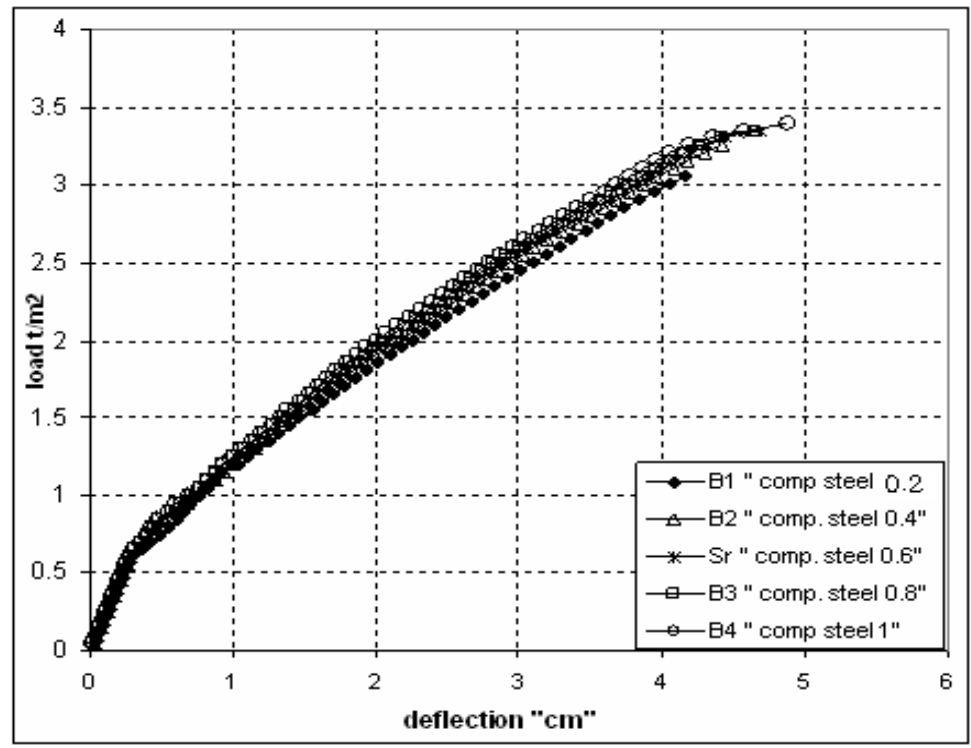

Fig. (21) load- deflection curve at mid span of rib

It was observed that the change of compression steel has slightly effect on the maximum strain of concrete and maximum stress of steel of the rib as shown in Fig. 22. 


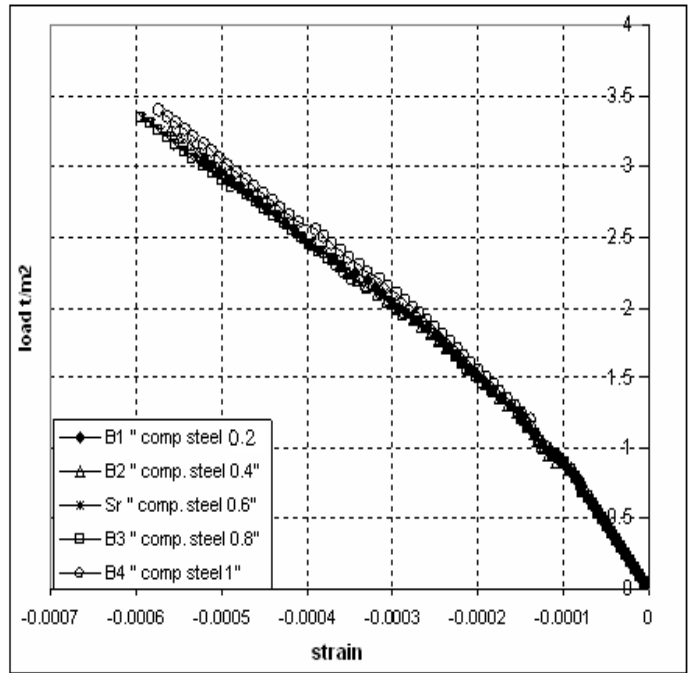

a)Load-strain curve of concrete at top fibers

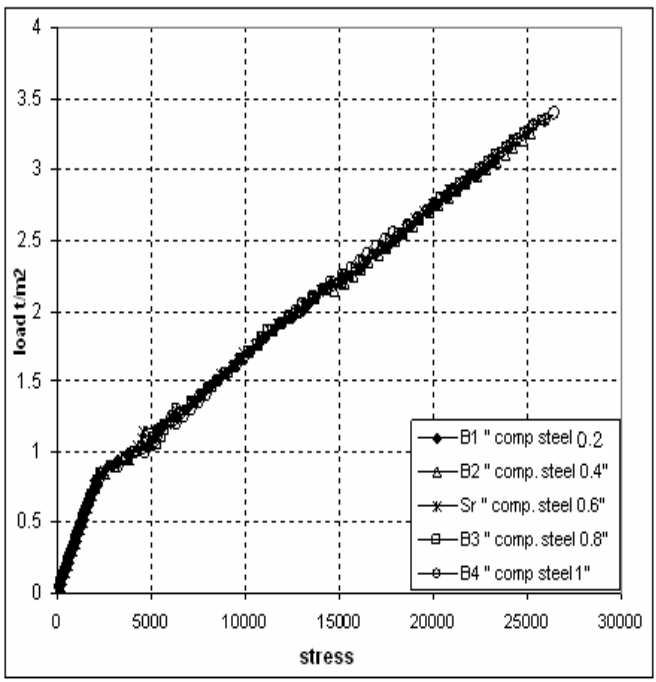

(b) load- stress" $t / \mathrm{m}^{2}$ " curve of steel at bottom fibers

Fig. (22) load- strain and stress curve at mid section of rib

The relationship between load and deflection are shown in Fig. 23 respectively. Increasing the compression steel, the maximum deflection of solid part decreases. This is due to increase of rigidity of solid part.

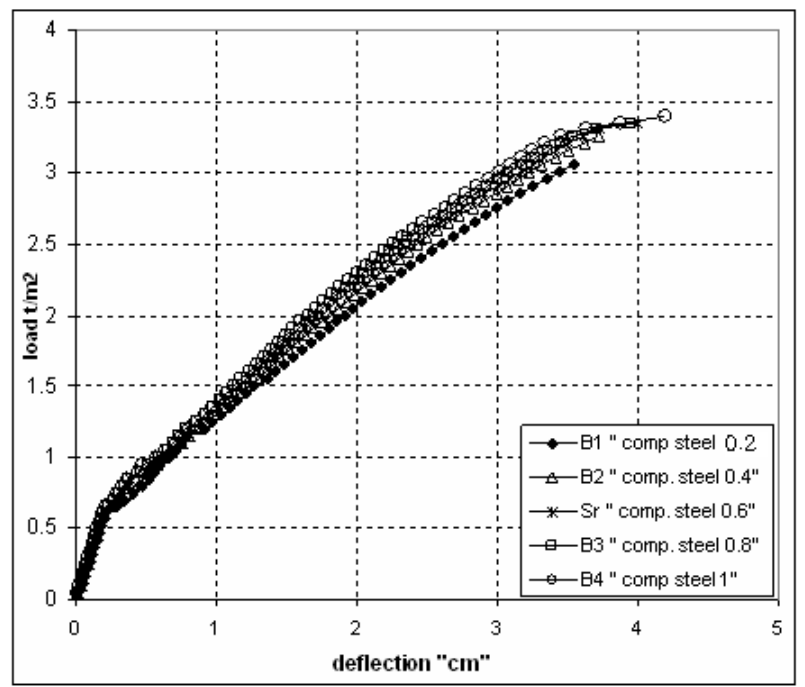

Fig. (23) load- deflection curve at mid span of solid part.

The strain of concrete at top fibers and stress of main steel at bottom fibers of middle solid part are shown in Fig. 24.

The strain of concrete decreases as the compression steel increases. While the effect of increase of compression steel on the stress of main steel was small. 


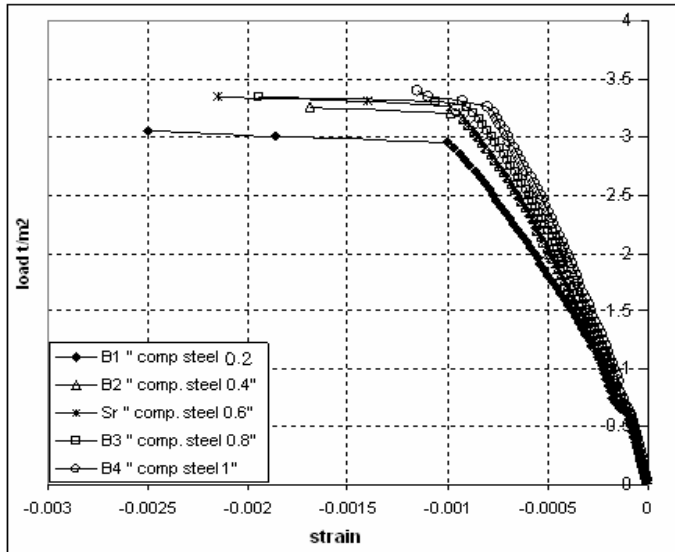

a) load- strain curve of concrete at mid section of solid part

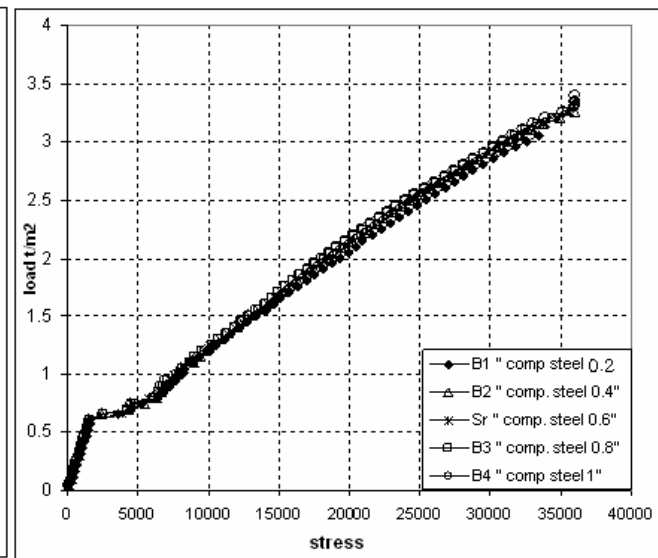

(b) load- stress" t/m ${ }^{-}$" curve of steel at mid section of solid part

Fig. (24) load-strain and stress curve at mid section of solid part

\subsubsection{The Effect of Edge Solid Parts}

\section{A) The Width of Perpendicular Solid Part}

\section{A.1) Cracking Load, Modes of Failure and Ultimate Load.}

Increasing the width of perpendicular solid part, the cracking load was nearly constant. The cracking load of slabs was occurred at the mid section of solid part. The cracking load and B/L of perpendicular edge solid part curve is shown in Fig. (25).

The existence of perpendicular edge solid part was effective on the ultimate load. While the increase of the width of perpendicular edge solid part from $0.3 \mathrm{~m}$ to $0.8 \mathrm{~m}$ has slightly effect on the ultimate load.

The ultimate load and $\mathrm{B} / \mathrm{L}$ of perpendicular edge solid part curve is shown in Fig. (26) The final modes of failure for slabs K2 and K3 were tension flexural failure caused by yielding of the tension reinforcement of middle solid part. While the final mode of failure for slab K1 was compression failure due to the principles stress at the bottom fiber of the connection between the middle rib and the supported beam. The principles stress due to the combined of shear stress and normal compression stress.
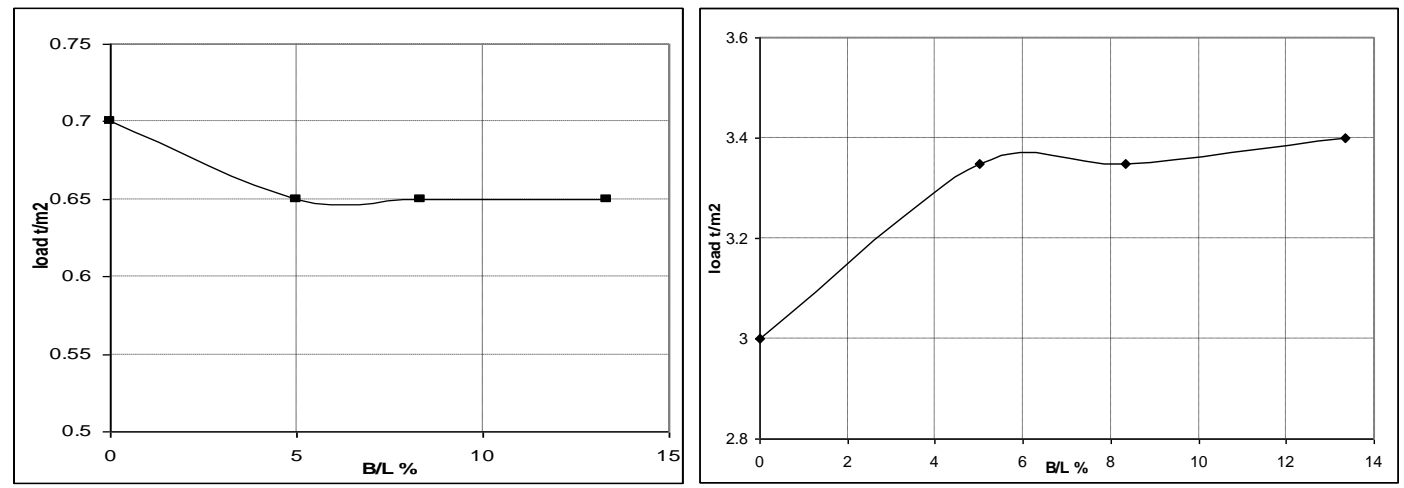

Fig. (25) The relationship between B/L and Pcr Fig (26) The relationship between B/L and Pu 


\section{a.2)- Deformations and Stress of the Middle Rib and Solid Part .}

The relationship between $\mathrm{B} / \mathrm{L} \%$ and maximum deflection at mid section of middle rib and the load deflection curve are shown in Figs (27 and 28) respectively. The maximum deflection at mid section of the rib decreases as the width of perpendicular solid part increases. And the stiffness of slabs increases.

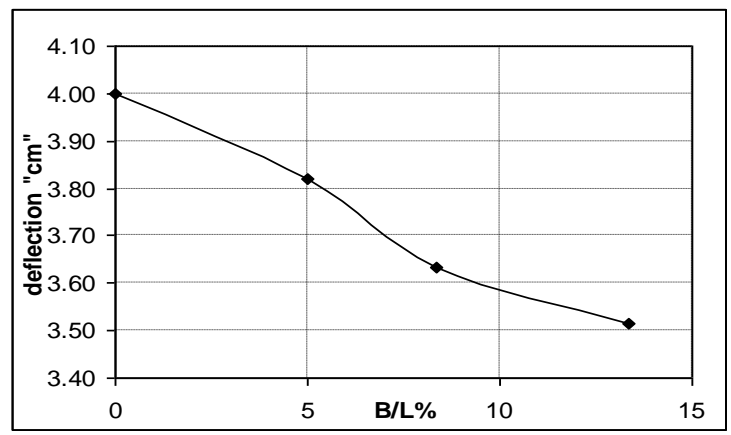

Fig (27) The relationship between B/L\% and maximum deflection at mid section of middle rib

It was observed that the change of width of perpendicular edge solid part has pronounced effect on the stress and strains at the connection between the rib and perpendicular edge solid part. This is may be because of decreasing the width of edge solid part, the deflection and the rotation at the connection zone decreases and the rigidity of this connection increases. Due to this, high stress and strains produce at this connection. Also the high stress and strains at this zone due to the increase of the length of ribs.

However the increase of the width of perpendicular edge solid part and decrease the length of the rib, the induced strains and stress at the middle of the rib is nearly constant. This is may be because that the increase of edge solid part causes decreasing the rib restrain at the connection between the rib and perpendicular edge solid part and the negative bending moment at this zone decreases. So, the induced bending moment at the middle of the rib is nearly constant.

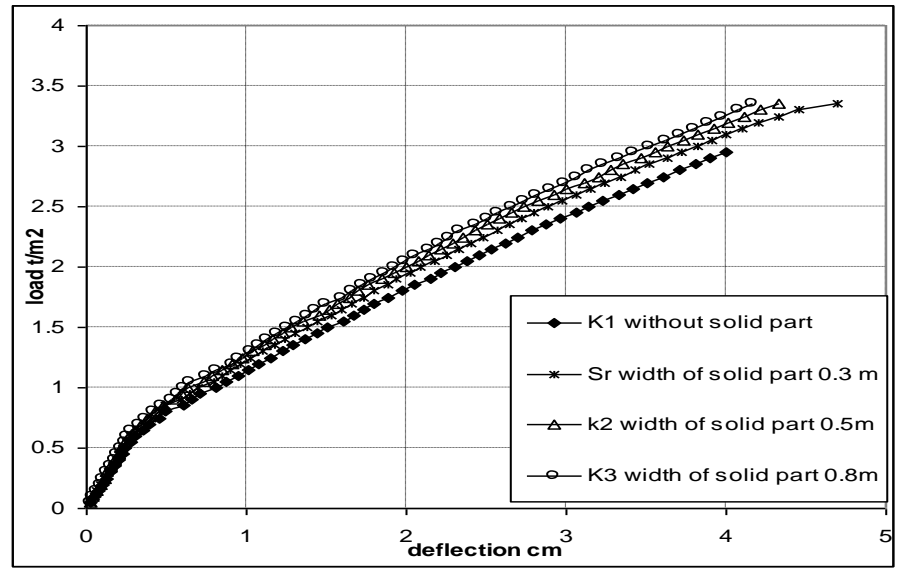

Fig (28) load- deflection curve at mid span of rib 
The load - strain curve of concrete and the load - stress curve of steel of the rib are shown as Figs. 29 to 30.

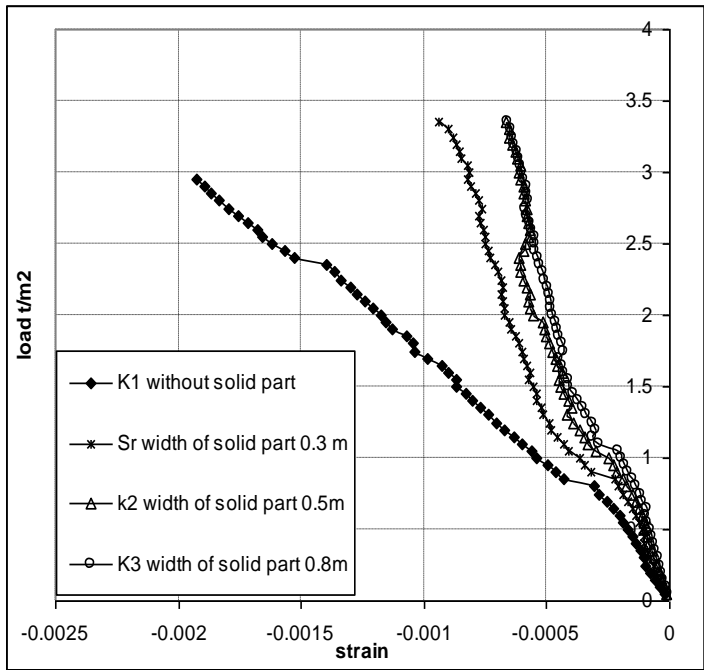

a)Load-strain curve of concrete at bottom fibers

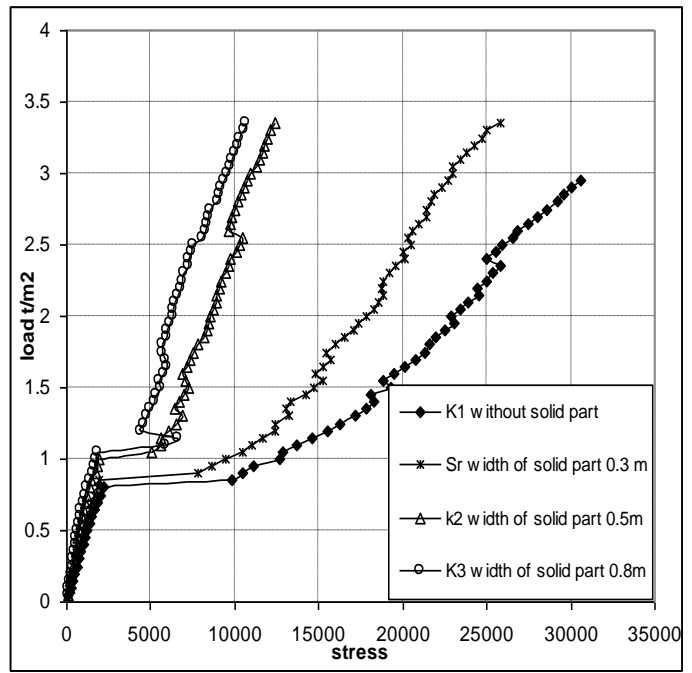

(b) load- stress" $\mathrm{t} / \mathrm{m}^{2}$ " curve of steel at top fibers

Fig (29) load- strain and stress curve at the connection between the rib and perpendicular edge solid part

The relationship between load and deflection, the load - strain curve of concrete and the load - stress curve of steel at mid of the middle solid part are shown in Figs 31 to 32 respectively.

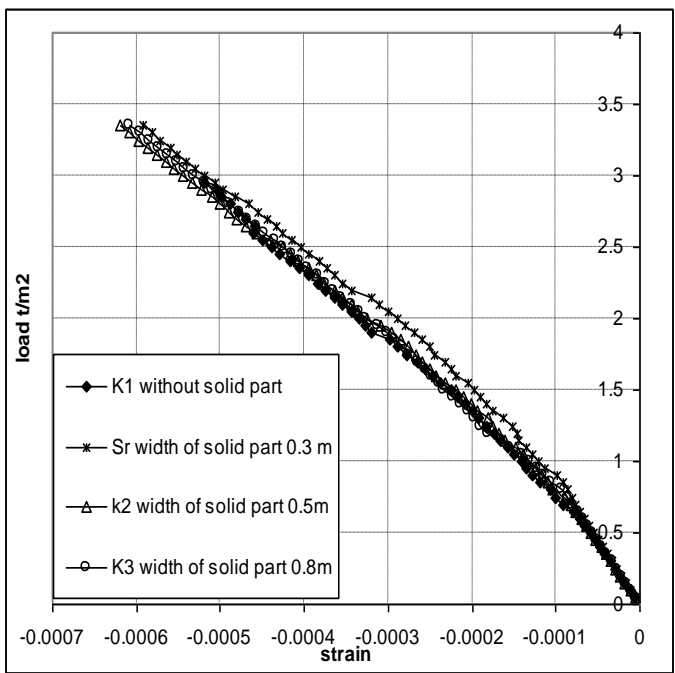

a)Load-strain curve of concrete at top fibers

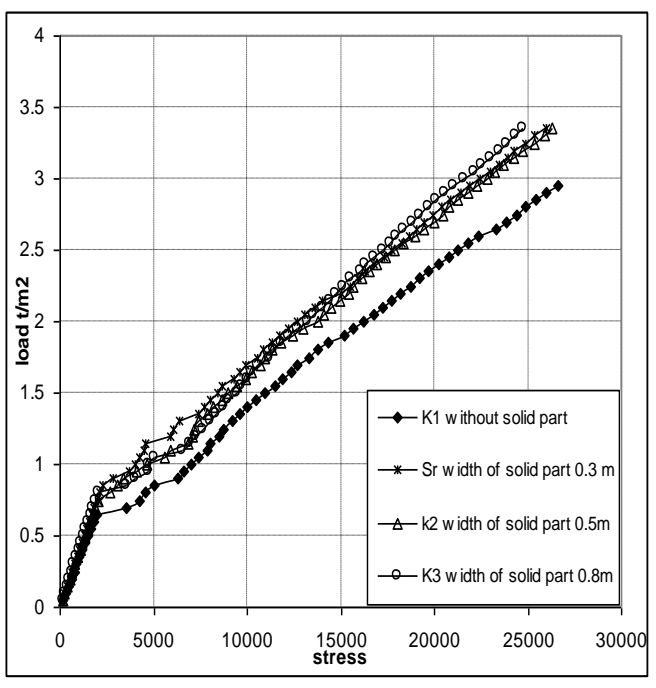

(b) load- stress" t/m ${ }^{2}$ curve of steel at fibers bottom

Fig. (30) load- strain and stress curve at middle the rib 
Increasing the width of perpendicular edge solid part has small effect on the induced deformations and stress of the middle solid part.

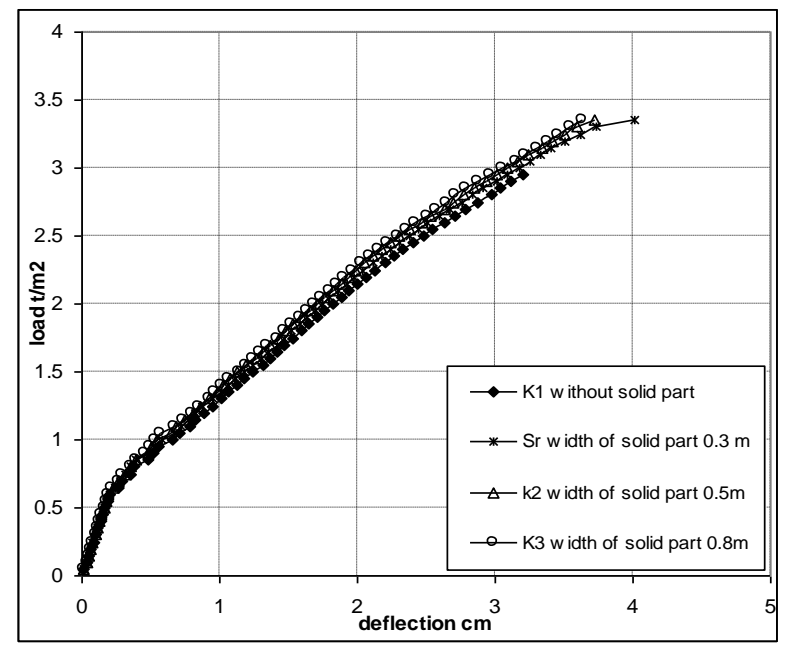

Fig. (31) The load - deflection curve at mid span of solid part

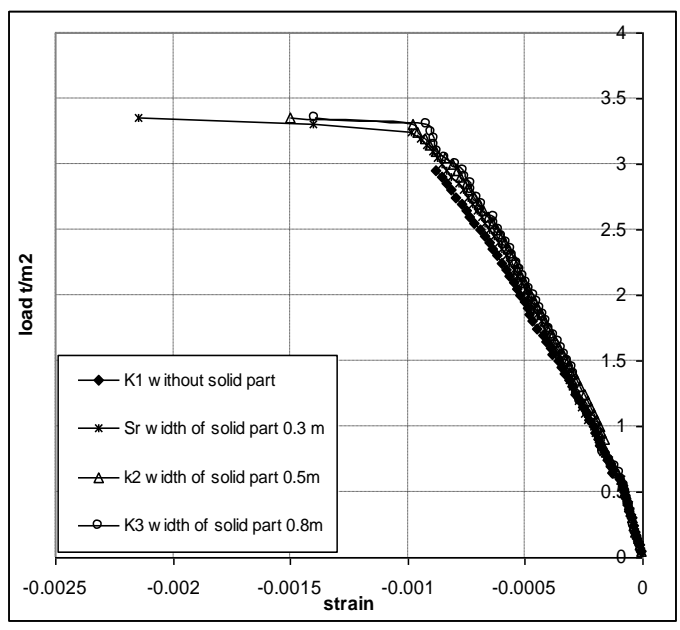

a) load- strain curve of concrete at mid section of solid part

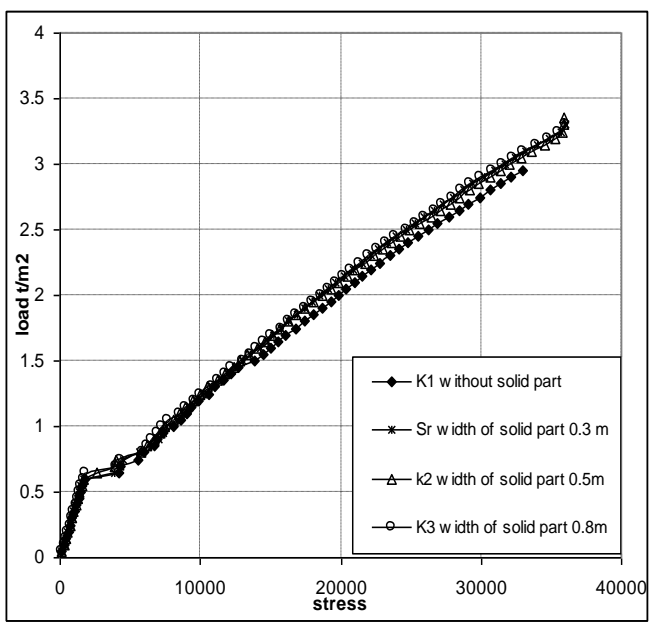

(b) load- stress" $\mathrm{t} / \mathrm{m}^{2}$ " curve of steel at mid section of solid part

Fig (32) load-strain and stress curve at mid section of solid part

\section{B) The Width of Parallel Solid Part}

\section{B.1) Cracking Load, Modes of Failure and Ultimate Load .}

The parallel edge solid part has pronounced effect on the behavior of slabs comparison with the effect of perpendicular solid part and middle solid part. The cracking load of slabs was occurred at the mid section of solid part. The cracking load, the ultimate load and $\mathrm{B} / \mathrm{L} \%$ of perpendicular edge solid part curves are shown in Figs (33) and (34) respectively. 
The ultimate load increases as the width of edge solid part increases. The final modes of failure for slabs of group $\mathrm{L}$ were tension flexural failure caused by yielding of the tension reinforcement of middle solid part.

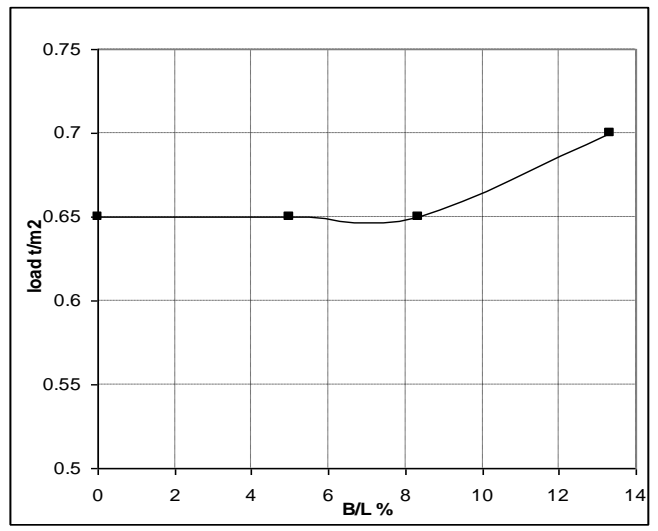

Fig (33) The relationship between B/L and Pcr

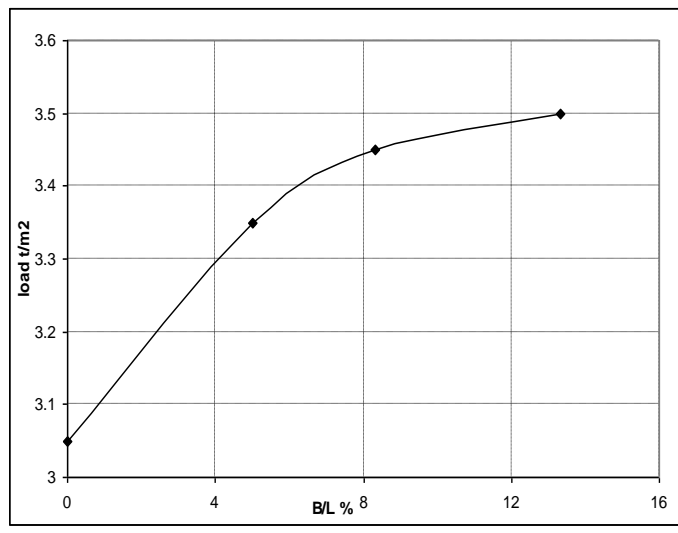

Fig (34) The relationship between $\mathrm{B} / \mathrm{L}$ and $\mathrm{Pu}$

\section{B.2)- Deformations and Stress of the Middle Rib and Solid Part.}

The relationship between $\mathrm{B} / \mathrm{L} \%$ and maximum deflection at mid section of middle rib and the load deflection curve are shown in Figs (35 and 36) respectively.

The maximum deflection at mid section of the rib decreases as the width of perpendicular solid part increases, and the stiffness of slabs increase.

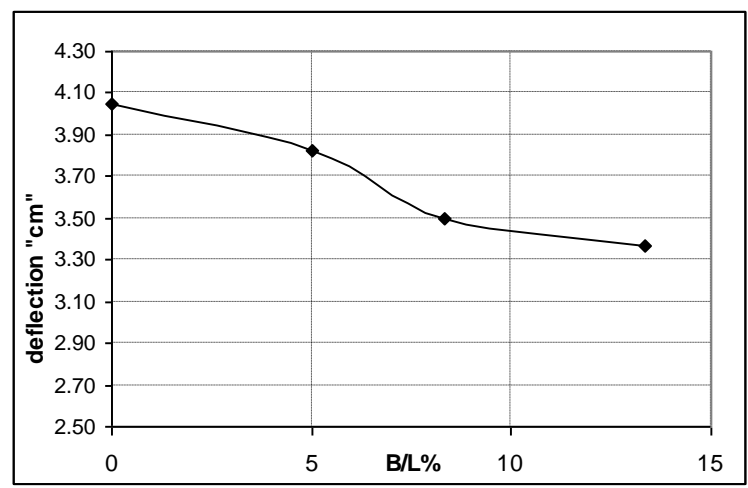

Fig (35) The relationship between $\mathrm{B} / \mathrm{L} \%$ and maximum deflection at mid section of middle rib

It was observed that the deformations and stress at the middle of the rib decreases as the width of parallel solid part increases. This indicates that the produced moments decrease. This is may be because that with increasing the width of parallel solid parts, the rigidity of top slab in the perpendicular direction of the ribs increases. Due to this the separated loads in the perpendicular direction of the ribs increase and the loads on the ribs decrease. The load - strain curve of concrete and the load - stress curve of steel of the rib are shown in Fig. 37 a and b. 


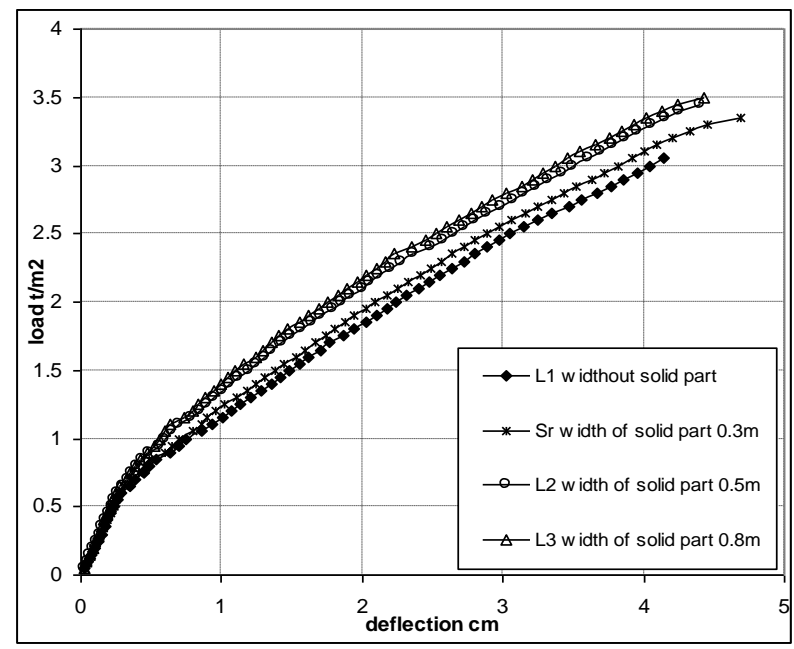

Fig. (36) load- deflection curve at mid span of rib

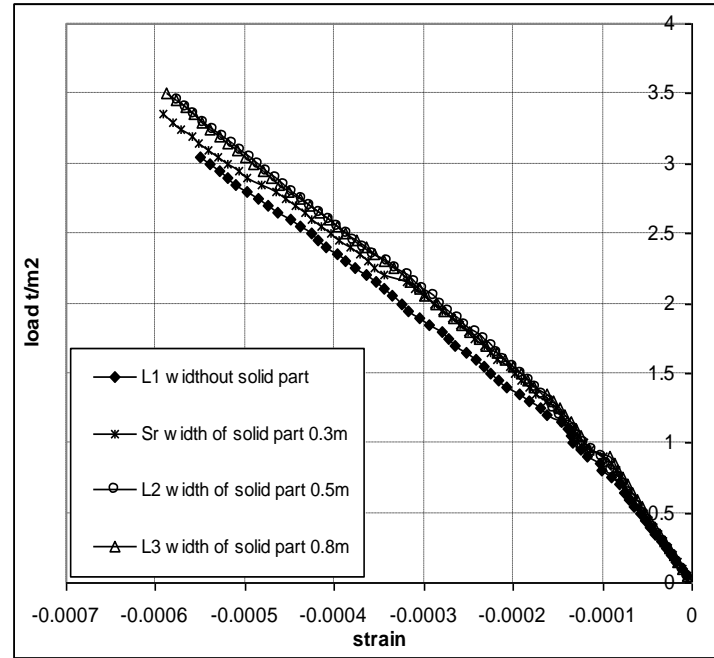

(a)Load-strain curve of concrete at top fibers

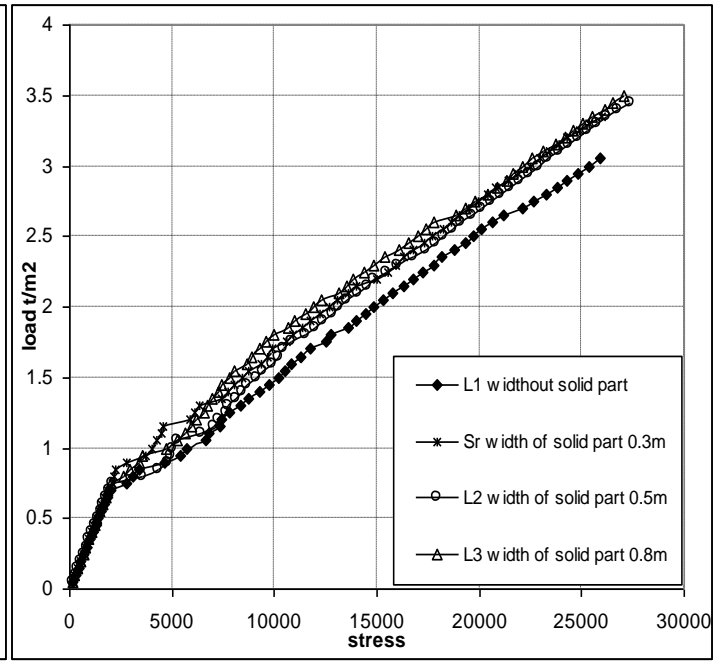

(b) load- stress" t/m " curve of steel at bottom fibers

Fig. (37) load- strain and stress curve at the middle of rib

The load - deflection curve, load-strain curve of concrete and load-stress of steel curve at mid section of the middle solid part are shown in Figs 38 and 39.

The induced deformations and stress at the middle of solid parts decrease as the width of parallel solid parts increases. This is may be because that the increase the rigidity of top slab in the perpendicular direction of the ribs as mentioned before. This causes decreasing the reactions of the ribs on the solid part. 


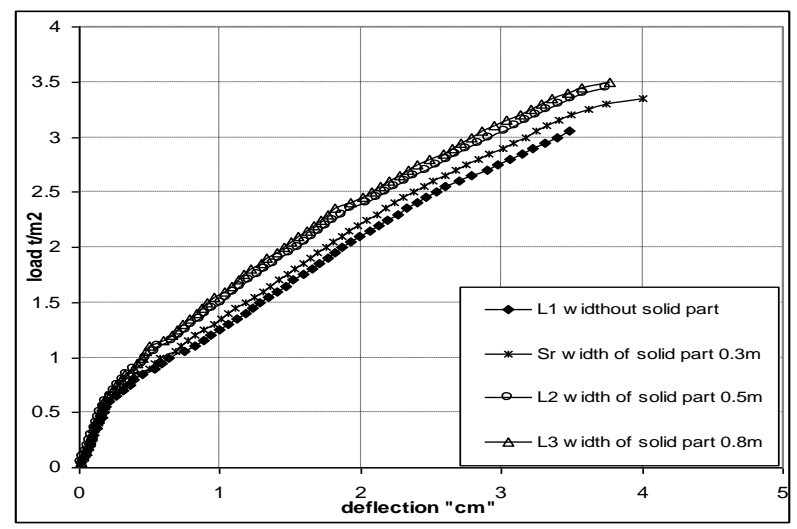

Fig. (38) The load - deflection curve at mid span of solid part

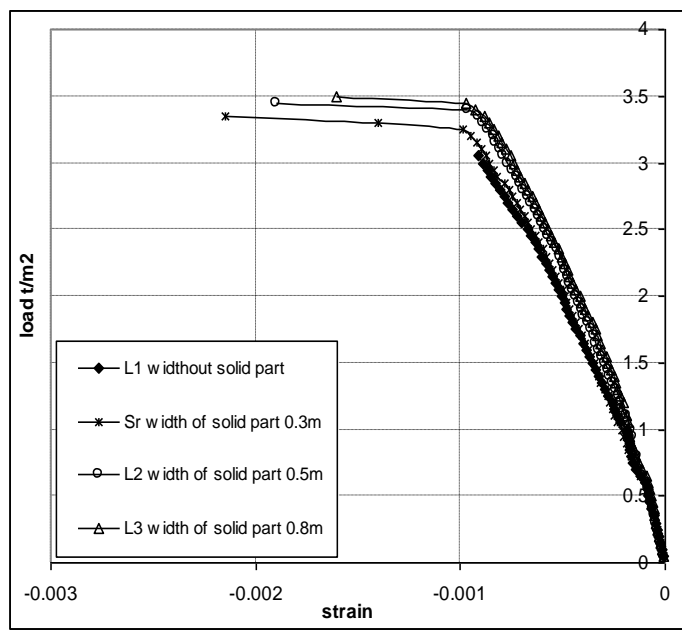

a) load- strain curve of concrete at mid section of solid part

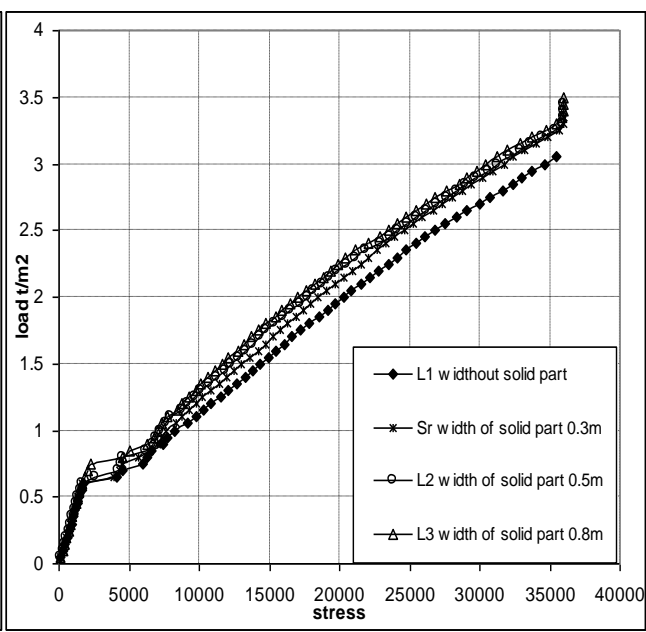

(b) load- stress" $t / \mathrm{m}^{2}$ " curve of steel at mid section of solid part

Fig. (39) load-strain and stress curve at mid section of solid part

\section{CONCLUSIONS}

The following conclusions have been drawn out of the presented study:-

1) The best width of middle solid part for the studied slabs was $30 \% \mathrm{~L}$. The effect of increase of width of middle solid part from $23.33 \% \mathrm{~L}$ to $30 \% \mathrm{~L}$, on the ultimate load, the cracking load and the maximum deflection are recognized and bigger than the effect of increase of width of middle solid part over than $30 \% \mathrm{~L}$ until $36.66 \% \mathrm{~L}$

2) The increase of compression steel has small effect on the behavior of slabs in comparison with the cost of material. The $567 \%$ increase of ratio of compression steel from slab B1 to slab B4 increases the ultimate load by ratio $11.5 \%$ and decreases the maximum deflection by ratio $10 \%$.

3) The effect of the width of edge solid parts was clear and bigger than the effect of width of middle solid part on the behavior of studied slabs. 


\section{REFERENCES}

1. American concrete institute (ACI-318-02) 2002.

2. Bangash M.Y.H (Concrete and Concrete Structure: Numerical Modeling and Applications) Elsevier Science Publishers Ltd.,London, England 1989.

3. British Standard Code OF Practice (BS 8110-97) 1997.

4. Cope, R.J., and Clark, L.A, "Concrete slabs: analysis and design " Elsevier applied science publishers, London and New York, 502pp,(1984)

5. Desayi, $\mathrm{P}$ and Krishnan, $\mathrm{S}$ (Equation for the Stress-Strain Curve of Concrete ) Journal of the American concrete institute, 61, pp.345-350, March 1964.

6. Egyptian code for design and construction of reinforcement concrete structures . ECP 203,2007

7. Gere, J .M and Timoshenko, S.P.(Mechanics of Materials)PWS publishing company, Boston , Massachusetts, 1997.

8. Sahah, S.P., Swartz, S.E. and Ouyang, C. (Fracture Mechanics of Concrete)John Wily \&Sons,Inc. New York, 1995.

9. Shaker El-Behairy (Reinforced Concrete Design Handbook), Ain Shams University, Sixth Edition,2004.

\section{تأثير الاجزاء المصمته على السلوك اللاخطى للبلاطات ذات الاعصاب فى اتجاه واحد}

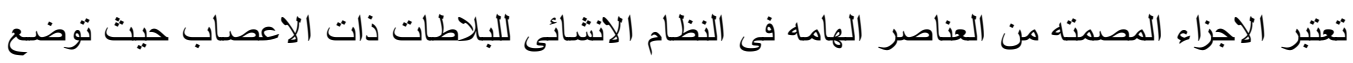
هذه الاجزاء عند التقاء الاعصاب بالكمرات الحامله للاعصاب وذللك لمقاومه القوى الداخليه الزائده عن السعه التحميليه للاعصاب. كما يمكن ان تستخدم هذه الاجزاء فى البلاطات ذات الاعصاب المستمره

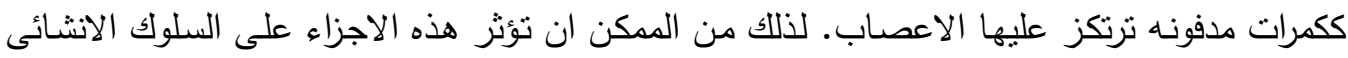

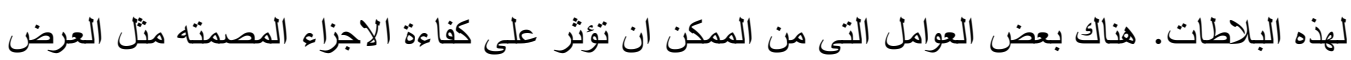

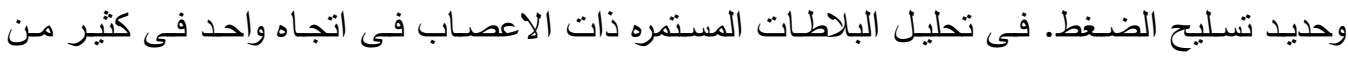

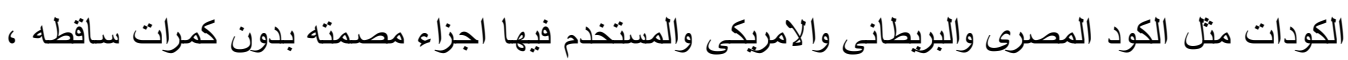
لا توجد حدود معينه لعرض هذه الاجزاء او حديد تسليح الضغط انما ينت تحليلها ككمرات مدفونه حامله للاعصاب وينم حساب عرض الاجزاء وحديد الضغط على هذا الاساس.

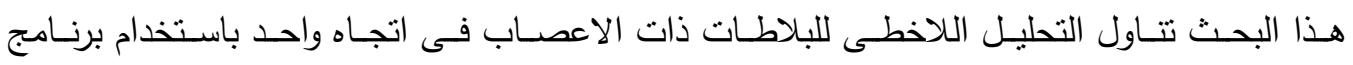

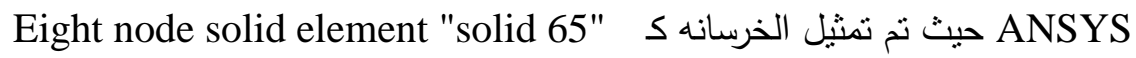

وتمثيل الحديد " Three-dimensional bar element "link كما تتاولت هذه الدراسه تاثير عرض الاجزاء المصمته الواقعه فى منتصف البلاطه وتسليح الضغط بها

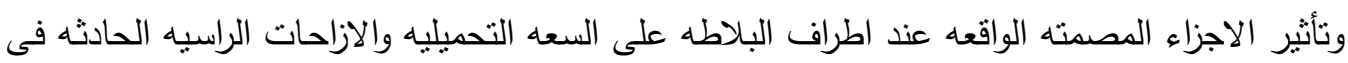


البلاطات والانفعالات المتولده فى العصب الاوسط والجزء المصدت الاوسط. وقد اوضحت النتائج ان افضل عرض للجزء المصدت الاوسط للبلاطات المدروسه هو 30\% من طول الباكيه. وان تأثير حديد

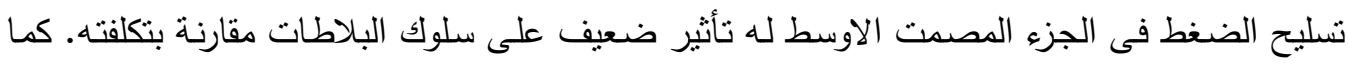

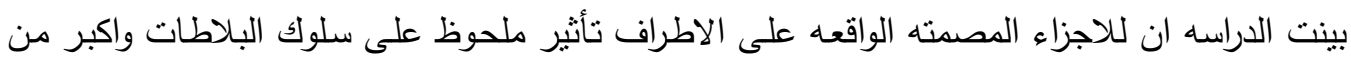

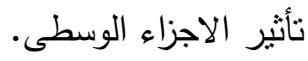

